\title{
PENGARUH SENAM KAKI TERHADAP SENSITIVITAS KAKI PADA PENDERITA DIABETES MELITUS DI PUSKESMAS MEDAN TUNTUNGAN TAHUN 2015
}

\author{
EIny Lorensi Silalahi, Surita Ginting, Anita Johana Marpaung \\ Jurusan Keperawatan Pultekkes Medan
}

\begin{abstract}
Gymnastic of foot is activity or practice for the patient for the patient with diabetes mellitus to prevent the injury and for the blood circulation on foot (Suryadi, 2004). The objective of foot gymnastic is to improve the blood circulation on the foot of patient with diabetes mellitus for the circulation of nutrition on the organ (Tara, 2003). Sensitivity of foot is sensitivity on the lower extremity. This research applies pretest-posttest design in wich this research was conducted by do the initial observation (ptetest) before the intervention. After the intervention, the observation is conducted from the observation sheet. The resulth of research before the intervention of foot gymnastic indicates that the less sensitivity is 15 respondents (50\%), medium sensitivity is 8 respondents (26,7\%), good sensitivity for 7 respondent $(23,3 \%)$ and after the intervention of foot sensitivity, the medium sensitivity to be 18 respondent (78,3\%), good sensitivity for 5 respondents $(21,7 \%)$. The result of statistical test has a significant result to the increasing of sensitivity of foot where $p=$ 0,00 with the average value of increasing is 0,67 .
\end{abstract}

Keywords: Gymnastic offoot, Sensitivity of foot

\section{LATAR BELAKANG}

Diabetes melitus merupakan penyebab utama amputasi ekstermitas bawah non traumatic di Amerika Serikat. Sebanyak 50\% amputasi yang dilakukan di Amerika Serikat disebabkan karena teradinya kerusakan akibat diabetes. Berdasarkan hasil penelitian, didapatkan sekitar $60,3 \%$ orang yang mengalami diabetes melitus mengalami komplikasi neuropaty sensorik atau kerusakan serabut saraf sensorik akan menyebabkan ganguan sensasi rasa getar, rasa sakit, rasa kram, semutan, rasa baal, ransang ternal atau suhu, dan hilangnya refleks tendo pada kaki sehingga akan menyebabkan gangguan mekanisme protektif pada kaki. Saraf sensorik ini merupakan sistem saraf yang pertama kali terganggu pada diabetes melitus sebelum sistem saraf motorik dan otonom (Yunir, 2006).

Diabetes melitus terbagi atas diabetes melitus tipe I jika pankreas hanya menghasilkan sedikit atau sama sekali tidak menghasilkan insulin sehingga penderita selamanya tergantung insulin dari luar,biasanya terjadi pada usia kurang dari 30 tahun. Diabetes melitus tipe II adalah keadaan pankreas tetap menghasilkan insulin, kadang lebih tinggi dari normal tetapi tubuh membentuk kekebalan terhadap efeknya. Biasanya terjadi pada usia di atas 30 tahun karena kadar gula darah cenderung meningkat secara ringan tapi progresif setelah usia 50 tahun terutama pada orang yang tidak aktif dan mengalami obesitas (Smeltzer \& Bare, 2002).
Sepuluh besar negara dengan prevalensi DM tertinggi di dunia pada tahun 2000 adalah India, Cina, Amerika, Indonesia, Jepang, Pakistan, Rusia, Brazil, Italia, dan Bangladesh. Pada tahun 2030 India, Cina, dan Amerika diprediksikan tetap menduduki posisi tiga teratas negara dengan prevalensi DM tertinggi. Sementara Indonesia diprediksikan akan tetap berada dalam sepuluh negara dengan prevalensi DM tertinggi pada tahun 2030 (Wild, Roglic, Green, et al, 2004).

Indonesia menempati urutan ke-4 terbesar dalam jumlah penderita diabetes melitus di dunia. Pada tahun 2006 jumlah diabetes di Indonesia diperkirakan mencapai 14 juta orang, baru $50 \%$ yang sadar mengidapnya dan diantaranya baru sekitar $30 \%$ yang datang berobat teratur (WHO, 2008). Kesadaran keluarga maupun masyarakat dalam mengantisipasi akibat yang ditimbulkan sangat diperlukan untuk menekan angka kejadian diabetes melitus termasuk juga di Indonesia.

Berdasarkan data yang diperoleh dari data Survailans Terpadu Penyakit (STP) tahun 2008 terlihat jumlah kasus yang paling banyak adalah penyakit Diabetes Melitus dengan jumlah kasus Diabetes Melitus mencapai 918 pasien yang ada di 123 rumah sakit 28 kota/ kabupaten seluruh provinsi Sumatra Utara, data Riskesdas (2007) prevalensi Diabetes Melitus yang di diagnosa oleh Nakes (tenaga kesehatan) disertai dengan gejala diperoleh data untuk Samosir 0,3\%, Dairi 0,1\%, Serdang Bergadai 0,6\%, Tapanuli Utara 0,3\%, prevalensi Diabetes Melitus untuk kota Medan 2,7\% dan prevalensi Diabetes 
Melitus untuk provinsi Sumatra Utara 1,98\%, sementara data terakhir yang dikeluarkan Depkes RI menyatakan prevalensi DM secara nasional adalah 5,7\% (Depkes, 2009).

Puskesmas Medan Tuntungan melaporkan untuk penderita diabetes melitus di tahun 2014 sebanyak 454 pasien sedangkan dibulan Februari tahun 2015 sebanyak 72 pasien dan yang sering berobat di bulan Februari tahun 2015 adalah sebanyak 30 pasien dan mengeluh gangguan sensitivitas kaki.

Cavanagh pakar kaki pada diabetik dari Claveland US, menyoroti problem kaki di masa yang akan datang, dimana pada tahun 2032 seiring dengan peningkatan jumlah penyandang diabetes melitus dunia akan terjadi pula lonjakan masalah kaki diabetik. Di negara Cina, dengan jumlah penduduk yang lebih dari 1 milyar, saat ini diperkirakan terdapat 40 juta penyandang diabetes, jika di perkirakan $10 \%$ diantaranya mengalami problem kaki diabetik maka akan terdapat 4 juta penyandang diabetes yang mengalami problem kaki diabetik. Berdasarkan epidemiologi di Amerika Serikat ditemukan sekitar 250.000 orang meninggal akibat tidak melakukan latihan fisik tidak secara teratur. Latihan fisik secara teratur akan mencegah atau mengurangi resiko terserangnya bibit penyakit (Hitchcock, 1999).

Neuropati perfifer (kerusakan saraf) merupakan komplikasi serius dari diabetes. Data terbaru menunjakkan bahwa 1 dari 5 orang dengan diabetes $(20 \%)$ mengalami neuropati perifer. Resiko neuropati perifer dapat terjadi sekitar 2 kali lipat lebih tinggi dibandingkan dengan orang tanpa diabetes. Kombinasi neuropati perifer dengan masalah yang terkait dengan suplai darah ke kaki dapat menyebabkan ulkus kaki dan penyembuhan luka lambat. Infeksi ini dapat menyebabkan luka amputasi, 40-70\% dari

Dasar pengobatan yang dapat dilakukan ketika sudah terjadi komplikasi hanyalah dengan cara mengontrol kadar gula darah semaksimal mungkin untuk mencegah terjadinya keadaan yang lebih buruk, karena neuropati akan terus berlangsung seiring perjalanan penyakit diabetes melitus yang diderita. Penanganan neuropati ini dapat dilakukan melalui tiga hal yaitu (1) penyuluhan atau pemberian nasehat, (2) pengobatan nyeri, dan (3) perawatan kaki (Tandra, 2007; Yunir, 2005). Perawatan kaki merupakan upaya pencegahan primer terjadinya luka pada kaki diabetes maupun gejala awal adanya kesemutan atau baal yang akan menyebabkan penurunan sensitifitas kaki. Salah satu tindakan yang harus dilakukan dalam perawatan kaki untuk mengetahui adanya kelainan kaki secara dini adalah dengan melakukan senam kaki diabetes, selain memotong kuku yang benar, pemakaian alas kaki yang benar, dan menjaga kebersihan kaki (Soegondo, et al, 2004). Diabetes melitus dapat diatasi dengan mengelola beberapa hal yang mempengaruhi penurunan glukosa, yaitu aktifitas, kadar insulin, diet, edukasi dan terpi (Perkeni, 2002; Smelzer \& Bare, 2002). Dilihat sudut ilmu kesehatan, tidak diragukan lagi bahwa olahraga atau latihan fisik apabila dilakukan sebagaimana mestinya menguntungkan bagi kesehatan dan kekuatan pada umumnya. Selain itu telah lama pula olahraga digunakan sebagai bagian pengobatan diabetes melitus namun tidak semua olahraga dianjurkan bagi pengidap diabetes melitus (bagi orang normal juga demikian), karna dapat menimbulkan halhal yang dapat diharapkan. Olahraga yang tepat dilakukan adalah olahraga yang terukur, teratur, terkendali dan berkesinambungan. Frekuensi yang dianjurkan adalah beberapa kali perminggu selama 30 menit atau lebih secara teratur dan tidak berlabihan (Hitchcock, 1999). Intensitas yang dianjurkan sebesar 40-70\%, aktifitas ringan sampai sedang (Ermita, 2009). Salah satu jenis olahraga yang dianjurkan pada penderita diabetes adalah senam kaki (Akhtyo, 2009).

Senam kaki diabetes adalah kegiatan atau latihan yang dilakukan oleh pasien diabetes melitus untuk mencegah terjadinya luka dan membantu melancarkan peredaran darah bagian kaki (Suryadi, 2004). Sedangkan menurut Setiawan 2010), senam kaki diabet merupakan salah satu terapi yang dilakukan perawat. Senam ini bertujuan untuk melancarkan peredaran darah yang terganggu karena senam kaki diabetes dapat membantu memperkuat otot-otot kaki. Senam kaki diabet ini bertujuan untuk memperbaiki sirkulasi darah sehingga nutrisi kejaringan lebih lancar, memperkuat otot-otot kecil, otot betis, dan otot paha, serta mengatasi keterbatasan gerak sendi yang sering dialami oleh penderita diabetes melitus, (Wibisono, 2009). Senam kaki diabet ini dapat diberikan kepada seluruh penderita diabetes melitus dengan tipe satu maupun dua.Namun sebaiknya diberikan senam kaki ini sejak pasien di diagnosa mendertia diabetes melitus sebagai tindakan pencegahan dini. Menurut Wibisono, yang menjadi ketua persatuan diabetes indonesia, senam kaki ini berpengaruh untuk memperbaiki sirkulasi darah dan meningkatkan sensitivitas kaki. Jika tidak dilakukan dapat menimbulkan terjadinya ganggren, selanjutnya meningkatkan resiko kecacatan atau morbiditas dan akhirnya meningkatkan beban hidup individu, keluarga, masyrakat dan pemerintah.Senam kaki ini sangat dianjurkan untuk penderita diabetes yang mengalami gangguan sirkulasi darah dan neuropati di kaki, tetapi di sesuaikan dengan kondisi dan kemampuan tubuh penderita. Gerakan dalam senam kaki diabet seperti yang disampaikan dalam 3rd National Diabetes Educators Training Camp Tahun 2005 dapat membantu memperbaiki sirkulasi darah di kaki. Mengurangi keluhan dari neuropati sensorik seperti: rasa pegal, kesemutan, gringgingen di kaki. Manfaat dari senam kaki diabet yang lain adalah dapat memperkuat otot-otot kecil, mencegah terjadinya kelainan bentuk kaki, meningkatkan kemampuan otot betis, dan paha, mengatasi keterbatasan gerak sendi, latihan seperti senam kaki diabet dapat membuat otototot dibagian yang bergerak berkontraksi (Soegondo, et all, 2004). Pengendalian faktor resiko diabetes melitus melalui modifikasi gaya hidup sebagian besar hanya dilakukan dengan mengurangi makanan yang manismanis. Selain itu para penderita cenderung untuk 
memeriksakan kesehatanya, jika ada peningkatan kadar gula darah menggambarkan kebiasaan hidup orang keturunan diabetes melitus mempunyai resiko enam kali terkena diabetes melitus dibandingkan dengan masyarakat yang tidak mempunyai riwayat keturunan .

Berdasarkan penelitian Sigit Priyanto (2012) mengenai pengaruh senam kaki terhadap sensitivitas kaki pada penderita diabetes melitus di Magelang. Penelitian eksperimen semu desain pre and post test group with control group. Sampel secara aksidental atau conveniece sampling, 63 responden. Instrumen penelitian menggunakan skala sensitivitas kaki. Senam kaki dilakukan selama 4 minggu. Hasil penelitian setelah diberikan senam kaki sensitivitas kaki lebih baik ( $p$ value 0,000).

\section{Desain Penelitian}

Penelitian ini merupakan jenis penelitian kuantitatif dengan desain penelitian yaitu pra eksperimental one group. Kelompok subyek diobservasi sebelum dilakukakan intervensi. Kemudian di observasi kembali setelah dilaksanakan intervensi (Sastroasmoro \& Ismael, 2010). Desain rancangan yang dipergunakan yaitu pre and post test group design with control group. Sensitivitas kaki sebelum dan sesudah diberikan intervensi senam kaki dilakukan penilaian untuk melihat pengaruh senam kaki terhadap peningkatan sensitivitas kaki penderita diabetes melitus di Puskesmas Medan Tuntungan Kecamatan Kemenang Tani Tahun 2015.

Gambaran skema penelitian yang dilakukan yaitu :

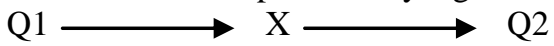

Q1 = Pengukuran sensitivitas kaki sebelum dilakukan intervensi senam kaki.

$\mathrm{X}=$ Intervensi senam kaki.

Q2 = Pengukuran sensitivitas kaki setelelah dilakukan intervensi senam kaki.

\section{Hasil Penelitian}

Diuraikan hasil penelitian dan pembahasan mengenai pengaruh senam kaki terhadap sensitivitas kaki pada penderita diabetes melitus di Puskesmas Medan Tuntungan tahun 2015 dengan jumlah responden 30 orang pasien diabetes melitus dengan ganguan sensitivitas kaki yang dilakukan pada tanggal 17 Juli 2015 - 31 Juli 2015.

\section{Analisa Univariat}

Analisa univariat dilakukan dengan menggunakan analisa distribusi, frekuensi, dan statistik deskriptif untuk melihat sensitivitas kaki sebelum dan sesudah dilakukan senam kaki.
Tabel 4.1 Distribusi $\quad$ Frekuensi Karaktristik Responden di Puskesmas Medan Tuntungan Tahun 2015

\begin{tabular}{cccc}
\hline No. & Karakteristik & Frekuesi & Persen \% \\
\hline 1. & Usia & & \\
& $26-45$ Tahun & 7 & 23,3 \\
& $46-55$ Tahun & 18 & 60 \\
& $56-65$ Tahun & 5 & 16,7 \\
Total & $\mathbf{3 0}$ & $\mathbf{1 0 0}$ \\
& Jenis Kelamin & & \\
2. & Laki - Laki & 21 & 70 \\
& Perempuan & 9 & 30 \\
\hline & Total & $\mathbf{3 0}$ & $\mathbf{1 0 0}$ \\
\hline
\end{tabular}

Berdasarkan tabel 4.1 dapat dilihat bahwa mayoritas responden yang berusia 26-45 sebanyak 7 orang $(23,3 \%)$, yang berusia 46-55 responden sebanyak 18 Orang $(60,0 \%)$ dan yang berusia 56-65 sebanyak 5 orang $(16,7 \%)$. Sedangkan menurut jenis kelamin laki- laki sebanyak 21 orang $(70,0 \%)$ dan yang berjenis kelamin perempuan sebanyak 9 orang $(30,0 \%)$.

Tabel 4.2 Distribusi Frekuensi Sensitivitas Kaki Sebelum Dilakukan Senam Kaki Pada Penderita Diabetes Melitus di Puskesmas Medan Tuntungan Tahun 2015

\begin{tabular}{cccc}
\hline No. & $\begin{array}{c}\text { Sebelum } \\
\text { Intervensi }\end{array}$ & Frekuensi & Persen \\
\hline 1. & $\begin{array}{c}\text { Sensitivitas } \\
\text { Kurang }\end{array}$ & 15 & $50 \%$ \\
2. & $\begin{array}{c}\text { Sensitivitas } \\
\text { Sedang }\end{array}$ & 8 & $26,7 \%$ \\
3. & Sensitivitas Baik & 7 & $23,3 \%$ \\
\hline & Total & $\mathbf{3 0}$ & $\mathbf{1 0 0 \%}$ \\
\hline
\end{tabular}

Berdasarkan tabel 4.2 dapat dilihat bahwa mayoritas yang sensitivitas kaki yang kurang sebanyak 15 responden (50\%), yang sensitivitas kaki yang sedang sebanyak 8 responden $(26,7 \%)$ sedangkan yang sensitivitas kaki yang baik sebanyak 7 responden yaitu $(23,3 \%)$.

Tabel 4.3 Distribusi Frekuensi Sensitivitas Kaki Sesudah Dilakukan Senam Kaki Pada Penderita Diabetes Melitus di Puskesmas Medan Tuntungan Tahun 2015

\begin{tabular}{cccc}
\hline No. & $\begin{array}{c}\text { Sesudah } \\
\text { Intervensi }\end{array}$ & Frekuensi & Persen \\
\hline 1. & $\begin{array}{c}\text { Sensitivitas } \\
\text { Kurang }\end{array}$ & 0 & $0 \%$ \\
2. & $\begin{array}{c}\text { Sensitivitas } \\
\text { Sedang } \\
\text { Sensitivitas } \\
\text { Baik }\end{array}$ & 18 & $78,3 \%$ \\
3. & Total & $\mathbf{2 3}$ & $\mathbf{1 0 0 \%}$ \\
\hline
\end{tabular}


Berdasarkan tabel 4.3 dapat dilihat bahwa mayoritas sensitivitas sedang sesudah diberikan senam kaki sebanyak 18 responden $(78,3 \%)$ sedangkan sensitivitas baik sebanyak 5 responden $(21,7 \%)$.

\section{Analisa Bivariat}

Analisa Bivariat yaitu analisa yang dilakukan untuk mengetahui perbedaan sensitivitas kaki sebelum dan sesudah dilakukan senam kaki pada penderita diabetes. Analisa bivariat dilakukan dengan uji statistik Pair $\mathbf{T}$ test karena data berdistribusi normal.

Tabel 4.4 Distribusi Frekuensi Sensitivitas Kaki Sebelum dan Sesudah Dilakukan Senam Kaki Pada Penderita Diabetes Melitus di Puskesmas Medan Tuntungan Tahun 2015

\begin{tabular}{lllll}
\hline No. & $\begin{array}{l}\text { Sensitivitas } \\
\text { Kaki }\end{array}$ & Mean & SD & P Value \\
\hline 1. & $\begin{array}{l}\text { Sensivitas } \\
\text { kaki sebelum } \\
\text { dilakukan } \\
\text { intervensi } \\
\text { sensitivitas } \\
\text { kaki }\end{array}$ & 1,76 & 0,81 & 0,00 \\
2. & & & \\
& $\begin{array}{l}\text { Setelah } \\
\text { dilakukan } \\
\text { intervensi }\end{array}$ & 2,43 & 0,5 & 0,00 \\
\hline
\end{tabular}

Dari tabel 4.4 dapat dilihat bahwa terdapat perbedaan rata- rata sensivitas kaki yang bermakna antara sebelum dan sesudah diberikan intervensi $(\mathrm{P}$ Value $<0,05)$. Sesudah dilakukan intervensi terjadi perubahan rata- rata sensivitas kaki sebanyak 0,67.

\section{PEMBAHASAN}

Perubahan nilai sensitivitas kaki sebelum dan sesudah diberikan intervensi di Puskesmas Medan Tuntungan. Berdasarkan hasil penelitian yang dilakukan menunjukkan perbedaan selisih mean ratarata sensitivitas kaki sebelum dengan sesudah intervensi. Hal ini menggambarkan bahwa penderita diabetes melitus yang diberikan intervensi memiliki sensitivitas lebih baik.

Hasil penelitian ini sesuai dengan penelitian sebelumnya yaitu Calle, Pascual, Duran, (2001) menyatakan bahwa diabetisi dengan neuropati dilakukan perawatan kaki diabet yang dilakukan dengan menjaga sirkulasi darah kaki dihasilkan kelompok yang tidak melakukan perawatan kaki 13 kali beresiko terjadinya ulkus diabetika dibandingkan kelompok yang melakukan perawatan kaki secara teratur. Esensi persamaan penelitian yang dilakukan dengan penelitian tersebut menunjukkan resiko terjadinya gangguan pada ekstermitas bawah atau kaki, jika penderita yang mengalami diabetes melitus diberikan latihan senam atau aktivitas. Sedangkan esensi perbedaan penelitian yang ditemukan dengan penelitian tersebut. Yaitu efek positif yang ditimbulkan pada penelitian Calle adalah terhadap sirkulasi darah sedang pada penelitian ini sensitivitas kaki, begitu juga penelitian Calle hanya

perawatan kaki secara umum, sedangkan penelitian ini dengan dilakukan dengan senam kaki.

Senam kaki merupakan salah satu bentuk keterampilan dimana untuk mencapai peningkatannnya diperlukan waktu yang lama dan teratur serta harus dipraktekkan.

Hal ini sesuai dengan penelitian Sahar (2002) yang menyebutkan bahwa ada peningkatan keterampilan secara signifikan setelah 6 bulan penelitian tersebut menunjukkan terjadinya peningkatan ketrampilan atau latihan sedangkan esensi perbedaan penelitian tersebut selama 6 bulan, sedangkan penelitian ini dilakukan selama 2 minggu.

Begitu pula penelitian Barnett, et, al (2003) mengemukakan bahwa latihan fisik yang dilakukan 1 jam per minggu selama satu tahun dapat menurunkan angka kerusakan sebesar $40 \%$. Intensitas dan kontinuitas dalam melakukan aktivitas atau latihan akan mempengaruhi efek yang ditimbulkan. Oleh karena itu senam kaki yang dilakukan secara teratur dan seimbang dapat berdampak positif bagi penderita Diabetes Melitus.

Hasil penelitian ini sesuai dengan penelitian di swiss oleh Rocher dikutip oleh Wibisono pada penderita diabetes melitus dengan neuropati, hasil penelitian olahraga tidak teratur akan beresiko terjadi ulkus diabetika lebih tinggi 4 kali dibanding dengan olahraga yang tidak teratur.

Perkini (2006) menyatakan perawatan kaki diabetesi yang teraturakan mencegah atau mengurangi terjadinya komplikasi kronik pada kaki. Menurut penulis aktifitas fisik khususnya senam kaki akan membantu menstimuli syaraf-syaraf kaki dalam menerima ransangan. Hal ini akan meningkatkan sensitivitas kaki terutama pada penderita diabetes melitus. Kondisi tersebut didukung hasil penelitian yang dilakukan di Puskesmas Medan Tuntungan yang menunjukkan peningkatan rata-rata sensitivitas kaki setelah dilakukan intervensi senam kaki.

Kerusakan saraf yang menuju ke kaki akan mengurangi rasa sensasi, dengan demikian kemampuan kaki untuk merasakan luka atau rasa tidak enak dan berkurangnya pasukan darah berarti bahwa luka yang kecil, mungkin sembuh tidak secepat biasanya. Kombinasi dari perubahan ini, berarti bahwa penderita diabetes melitus yang lansia beresiko terhadap infeksi dan luka pada kaki dan tenpa perawatan kaki yang baik maka keadaan ini dapat menjadi parah sehingga kadang-kadang harus berhenti bekerja atau bahkan jarang sekali melakukan aktifitas karena nyeri sangat hebat. Banyak penderita diabetes melitus yang mengalami ganguan peredaran darah, terutama pada kakinya. Pada penderita diabetes melitus akan merasakan perubahan sensitivitas pada kakinya setelah melakukan perjalanan jauh. Sensitivitas tidak dapat dirasakan lagi dan ini berarti bahwa pembuluh darah besar atau arteri di kaki menyempit atau tersumbat. 
Pada kasus-kasus tertentu pengobatan pembuluh darah secara operatif dapat membantu mengatasi masalah ini. Obat-obat biasanya tidak membantu mengatasi masalah tesebut. Terapi keperawatan dans enam kaki merupakan salah satu untuk mengatasi ganguan sensitivitas pada kaki penderita diabetes melitus. Menurut Waspadji (2005), senam kaki merupakan salah satu terapi yang diberikan seorang perawat, yang ebrtujuan untuk memperlancar peredaran darah yang tergangu karena senam kaki diabetes dapat membantu memperkuat otot-otot kaki. Senam kaki diabetes dapat membantu memperkuat otot-otot kaki. Senam kaki atau senam diabetes dapat membantu memperbaiki peredaran darah yang terganggu dan memeperkuat otototot kecil kaki pada pasien diabetes dengan neuropati. Selain itu dapat memperkuat oto-otot kecil kaki pada psien diabetes dengan neuropati. Selain itu dapat memperkuat otot betis dan otot paha, mengatasi keterbatasan gerak sendi dan mencegah terjadinya deformitas.

Komplikasi menahun dari diabetes melitus salah satunya adalah kelainan pada kaki diawali dengan terjadinya gangguan sensitivitas yang disebut sebagai kaki diabetik. Komplikasi yang paling sering dialami pengidap diabetes adalah komplikasi pada kaki $15 \%$ yang kini disebut kaki diabetes (Hendratmo, 2004, Wibowo, 2004, Cumha, 2005). Menurut Misnadiarly, 2007, di negara berkembang prevalensi kaki diabetik didapatkan jauh lebih besar dibandingkan dengan negara maju yaitu 2-4\%, prevalensi yang tinggi ini disebabkan kurang pegetahuan penderita akan penyakitnya, kurangnya perhatian tenaga kesehatan terhadap komplikasi serta rumitnya cara pemeriksaan yang ada saat ini untuk mendeteksi kelainan tersebut secara dini.

Pengelolaan kaki diabetes mencakup pengendalian gula darah, debridemen/ membuang jaringan yang rusak, pemberian antibiotik, dan obatobat vaskularisasi. Komplikasi kaki diabetik adalah penyebab amputasi ekstermitas bawah nontraumatik yang paling sering terjadi di dunia industri. Sebagian besar komplikasi kaki diabetik mengakibatkan amputasi yang dimulai dengan pembentukan ulkus di kulit. Resiko amputasi ekstermitas bawah 15-46 kali lebih tinggi pada penderita diabetik dibandingkan dengan orang yang tidak menderita diabetik dibandingkan dengan orang yang tidak menderita diabetes melitus. Selain daripada itu menurut Amstrong \& Lawrence, 1998, komplikasi kaki merupakan alasan tersering seseorang harus dirawat dengan diabetes, berjumlah $25 \%$ dari seluruh rujukan diabetes di Amerika Serikat dan Inggris.

Ganguan sensitivitas akan menyebabkan berkurangnya aliran darah dan hantaran oksigen pada serabut saraf yang kemudianmenyebabkan berkurangnya aliran darah dan hantaran oksigen pada serabut saraf. Keadaan ini akan mengakibatkan neuropati. Di samping itu, dari kasus ulkus/ gangren diabetes kaki diabetes melitus, 50\% akan mengalami infeksi akibat munculnya lingkungan gula darah yang subur untuk berkembangnya bakteri patogen. Karena kekurangan suplai oksigen, bakteri-bakteri yang akan tumbuh subur terutama bakteri anaerob. Hal ini karena plasma darah penderita diabetes yang tidak terkontrol dengan baik, mempunyai kekentalan (viskositas) yang tinggi. Sehingga aliran darah menjadi melambat. Akibatnya, nutrisi dan oksigen jaringan tidak cukup. Hal ini menyebabkan luka sukar sembuh dan kuman anaerob berkembang biak.

Menurut Thoha 2005, kondisi kaki diabetik berasal dari suatu kombinasi dari beberap penyebab seperti senaitivitas yang kurang dan neuropati. Berbagai kelainan seperti neuropati, angiopati yang merupakan faktor eksogen yang berperan terhadap terjadinya kaki diabetik. Sensitivitas kaki pada penderita diabetes melitus yang diawali angiopati diabetes disebabkan oleh beberapa faktor yaitu genetik, metabolik dan faktor resiko lainnya . kadar glukosa yang tinggi (hiperglikemia) ternyata mempunyai dampak negatif yang luas bukan hanya terhadap metabolisme karbihidrat, tetapi juga terhadap metabolisme protein dan lemak yang dapat menimbulkan pengapuran dan penyempitan pembuluh darah (aterokolosis). Akibatnya terjadi ganguan peredaran pembuluh darah besar dan kecil yang mengakibatkan sirkulasi darah kurang baik, pemberian makanan dan oksigenisasi kurang dan mudah menjadi terjadi penyumbatan aliran darah terutama daerah kkai. Neuropati diabetik dapat menyebabkan insentivitas atau hilangnya kemampuan untuk merasakan nyeri, panas, dan dingin. Menurut Mayfield, 1998, diabetes yang menderita neuropati dapat berkembang menjadi luka, parut, lepuh, atau luka karena tekanan yang tidak disadari akibat adanya insensitivitas. Apabila cidera ini tidak ditangani, maka akibatnya dapat terjadi komplikasi dan menyebabkan uleserasi dan bahkan amputasi. Neuropati juga dapat menyebakan deformitas seperti Buniion, Hammer (ibu jari martil), dan Charcot foot.

Penderita diabetik memerlukan perhatian penuh untuk mencegah kedua kaki agar tidak terkena cidera. Karena adanya konsekuensi neuropati, observasi setiap hari terhadap kaki merupakan masalah kritis. Sedangkan menurut Amstrong \& Lawrence, (1998) jika penderita diabetes memberikan perhatian terhadap aktivitas dan perawatan kaki, maka akan mengurangi risiko yang serius bagi kondisi kakinya, Cunha, (2005) mengemukakan sensitivitas yang kurang juga dapat menyebabkan pembengkakan dan kekeringan pada kaki. Pencegahan komplikasi pada kaki merupakan hal penting pada penderita diabetes melitus karena sensitivitas yang kurang merusak proses penyembuhan dan dapat menyebabkan ulkus, infeksi, dan kondisi pada kaki.

Proporsi kurangnya latihan fisik yaitu kebiasaan olahraga atau senam kaki kurang dari 3 kali dalam seminggu selama 30 menit pada kasus sebesar $80,6 \%$ dan kontrol 30,6\%. Sesuai dengan teori aktivitas fisik (olahraga) sangat bermanfaat untuk meningkatkan sensitivitas darah, menurunkan berat badan dan 
memperbaiki kadar glukosa darah. Menurut Yuni, (2006) dengan kadar glukosa darah terkendali maka akan mencegah komplikasi kronik diabetes melitus. Olahraga rutin (lebih 3 kali dalam seminggu selama 30 menit) akan memperbaiki metabolisme karbohidrat, berpengaruh positif terhadap metabolisme lipid dan sumbangan terhadap penurunan berat badan. Orang diabetes memiliki 3 alasan lebih tinggi resikonya mengalami masalah kaki. Pertama, berkurangnya sensasi rasa nyeri setempat (neuropati) membuat penderita tidak menyadari bahkan sering disebabkan karena trauma misalnya kemasukan air, tertusuk duri, lecet akibat pemakaian sepatu, sandal yang sempit dan bahan yang keras. Awalnya hanya kecil, kemudian meluas dalam waktu yang tidak begitu lama. Luka akan mejadi borok dan menimbulkan bau yang disebut gas gangren. Jika tidak dilakukakan perawatan akan sampai ke tulang yang mengakibatkan infeksi tulang (osteomylitis). Upaya yang dilakukan untuk mencegah perluasan infeksi terpaksa harus dilakukan amputasi (pemotongan tulang).

\section{KETERBATASAN PENELITIAN}

Keterbatasan penelitian yang terjadi, sebelum dilakukan intervensi senam kaki terhadap 30 responden terlebih dahulu peneliti melakukan pemeriksaan sensitivitas kaki (sensitivitas kurang 15 responden, sensitivitas sedang 8 responden, sensitivitas baik 7 responden), dimana pasien yang mengalami sesitivitas baik tidak mengikuti senam kaki hal ini terjadi karena responden mengalami sensitivitas baik sehingga pasien meminta untuk tidak mengikuti senam kaki dan tidak dipergunakan menjadi responden meskipun akhirnya jumlah responden seluruhnya adalah 23 orang. Responden terkadang ada yang tidak rutin dalam mengikuti senam kaki.

\section{KESIMPULAN}

Pengaruh senam kaki terhadap sensitivitas kaki pada penderita diabates melitus di Puskesmas Medan Tuntungan Tahun 2015 dapat diisimpulkan sebagai berikut :

1. Rata-rata sensitivitas kaki sebelum dilakukan senam kaki nilai sensitivitas kaki lebih rendah.

2. Rata-rata sensitivitas kaki setelah dilakukan senam kaki nilai sensitivitas kaki lebih tinggi.

3. Ada pengaruh sebelum dan sesudah dilakukan senam kaki terhadap sensitivitas kaki pada penderita diabetes melitus di Puskesmas Medan Tuntungan Tahun 2015.

\section{SARAN}

1. Bagi Pelayanan Kesehatan Agar pelayanan kesehatan dapat menerapkan senam kaki kepada pasien penderita diabetes melitus baik yang mengalami ganguan sensitivitas kaki dan yang tidak mengalami gangguan sensitivitas kaki agar mencegah terjadinya penurunan sensitivitas kaki.

2. Keluarga Bersama Dengan Pasien Agar keluarga ikut memberikan dukungan dan motivasi kepada pasien dalam melakukan senam kaki baik di rumah maupun saat pertemuan di puskesmas.

\section{DAFTAR PUSTAKA}

Akhtyo, (2009), Gambaran Klinis Hipoglikemia Pada Pasien Diabetes Melitus.

Jurnal Sigit Priyanto, (2012), Pengaruh Senam Kaki Terhadap Sensitivitas Kaki Pada Penderita Diabetes Melitus di Magelang, Jakarta : FIK UI.

Notoatmodjo, S. (2010). Metodologi Penelitian Kesehatan (Edisi Revisi). Jakarta: Penerbit Rineka Cipta.

Nursalam (2009). Konsep \& Penerapan Metodologi Penelitian Ilmu Kesehatan Pedoman Skripsi, Tesis, dan Instrumen Penelitian Keperawatan, Jakarta: Salemba Medika.

Perkini, (2002), Konsensus Pengelolaan Diabetes Melitus Di Indonesia. Jakarta: PB Perkini.

Price, (2005). Patofisiologi, Konsep, Penyakit-Penyakit , EGC, Jakarta.

Smeltzer \& Bare, (2002). Keperawatan Medikal Bedah Volume 2. Alih Bahasa Andry Hartono. EGC: Jakarta .

Soegondo. (2008), Melawan Diabetes Dengan Banyak Beraktivitas, diakses dari http://www.indodiabetes.com

Suyono, (2009), Kecenderungan Peningkatan Jumlah Pasien Diabetes. Jakarta: FKUI.

Tjokronegoro, A.(2002). Petunjuk Hidup Sehat Untuk Para Diabetis, Jakarta: PT.Gramedia Pustaka Utama.

WHO (2008), Technical Brief For Policy Maker, Geneva, Switzerland. 